\title{
Broadcasting and It's Receiving Agent Based M-commerce Business Model Functioning In The Market
}

\author{
Trivedi Jaydipkumar $\mathrm{H}^{1}$,Jitendra $\mathrm{H}$ Darji ${ }^{2}$,Parikh Pinakin $\mathrm{P}^{3}$,Trivedi Prakash $\mathrm{H}^{4}$ \\ ${ }^{I}$ Assistant professor, Merchant College Of Management Studies And Research, Visnagar,Gujarat,India. \\ ${ }^{2}$ Principal, Merchant Institute of Postgraduate Courses, Visnagar, Gujarat, India. \\ ${ }^{3}$ Assistant professor, Merchant College Of Management Studies And Research, Visnagar,Gujarat,India. \\ ${ }^{4}$ Assistant professor, G K \& C K Bosamiya college Jetpur, Gujarat, India.
}

\begin{abstract}
The study elaborately implies the Broadcasting agent and it's receiving agent based M-commerce business model functioning in the market. The work introducing recently invented M-commerce model and their related driving factor. Broadcasting and It's Receiving Agent Based M-Commerce business model stimulating business transaction which proves business model. The work instructing business transaction, which are performing through broadcasting agent and it's receiving agent. There are (1) Radio broadcasting agent, (2) Television broadcasting agent (3) satellite broadcasting agent (4) Web casting agent (5) Telephone broadcasting agent and (6) cable radio broadcasting which are working as broadcasting agent and there are its receiving agent. The architecture of $M$-commerce's broadcasting model depicting automatic and semi automatic transactions. ${ }^{[3]}$ In the automatic transactions there is embedded system for performing business transaction. The work throw the light on equations which are helping to prove the M-commerce's broadcasting model and their functionalities over an area of the Gujarat state in India. Questionnaire and their analysis using as research methodology. Primary and secondary data source have used for strengthening the study.
\end{abstract}

Keywords: - M-Commerce, Driving Factor

\section{INTRODUCTION}

The work introduces broadcasting and its receiving agent based m-commerce business model. The business transaction related to the market have noted as m-commerce transactions, which ultimately proves broadcasting and It's receiving agent based $\mathrm{m}$-commerce business model functioning in the market. The literature review denoted related work done by other researcher. The literature review denoted $\mathrm{M}$-commerce based research area and M-commerce model based research work. The work indicating (1) Prove the broadcasting and its receiving agent based $\mathrm{M}$-commerce business Model functioning in the market. (2) Considering the business transaction based on broadcasting and its receiving agent based $\mathrm{m}$-commerce based model.(3) Study the m-commerce as objectives of the research. Questionnaire and collection of data utilizing as research methodology. 1. M-commerce transaction can be performed through broadcasting agent and their receivers, 2. M-commerce transaction can be performed as automatically and semi automatically, 3. Mcommerce's broadcasting and its receiving agent based model functioning in the market noted as hypothesis of the work. There is an architecture of broadcasting and its receiving agent based M-commerce model. An architecture of broadcasting and its receiving agent based M-commerce model depicted automatic and Semi automatic transactions. The automatic transaction functioning with embedded system. M-commerce driving factors and equations played important role for proving the model. The observation of the transaction and analysis have performed using questionnaire. The work utilized primary and secondary data from the market.

\section{LITERATURE REVIEW}

The literature surveys undertaken for this research is centre around related work done by other researchers on $\mathrm{M}$-commerce models and its related works.

1. Jason J Zhang, Yufei Yuan,Norman Archar, Driving Force for M-commerce success. Indicates Driving Factors. ${ }^{[1]}$

2. Norman Sadeh, Forces behind the M-commerce "Revolution" have noted. The work explained certain forces.

3. AliKhatib, Abasanul Haque Hishamuddin Ismail and Shameem AlMohmud. The driving factors of ecommerce have denoted.

4. Trivedi Jaydipkumar, Dr J.G Pandya, Dr Ashish N Jani, Trivedi Prakashkumar Hitendrabhai Broadcasting and It's Receiving Agent Based M-commerce Business Model. Elaborately explain M-commerce model based on Broadcasting and It's Receiving Agent.

5. Stefan Figge, Kai Rannenberg, Inviting New Player To The Multimedia M-commerce Arena. It is a style to boost the current M-commerce business model with regards to emerging DVB-T networks. The research work indicates DVB which is using same terrestrial infrastructure (DVB-T) as traditional analog television, Which 
is becoming a mature technology with growing name of users. Many activities have noted for apply that infrastructure for distributing multimedia content and interactive services to mobile devices. The work is indicating presently television industry apply different business model more flexible than the mobile telecommunication industry does. The work suggest a style to expand the business model that is currently applied in the mobile telecommunication industry in order to make it competitive against broadcasted mobile multimedia services.

6. Roman Hogg,Robert Martignoni, Ketarina Stanoevska-slab eva, The impact of interactivity on mobile broadcasting value chain. Mobile Summit 2007. The research work indicates the impact of interactivity on mobile broadcasting values chains. It shows that the interactivity is a new source of revenue and the decisive factors for success of future mobile TV and other broadcasting services. Mobile broadcasting and interactivity are both emerging business models determining the forum of future mobile services business models. CMobile project is a research for interactive elements research. In the C-Mobile EU project, interactive broadcasting application have been discovered. The work explains the mobile broadcasting value chains. The work introduced interactive format which is describing the communication between the user and interactivity provider. In this context only TV as a barrier medium.

7.Trivedi Jaydipkumar Hitendrabhai, Dr J G Pandya, Trivedi Prakash H, Patel Jignasha B Rapid Growth Of Customer Use and Adoption of The Broadcasting Agent and Receiver: A Driving M-commerce Factor.

\section{OBJECTIVES}

(1) Prove the broadcasting and It's receiving agent based $\mathrm{m}$ - commerce business model functioning in the market.

(2) Considering the business transaction based on broadcasting and It's receiving agent based $\mathrm{m}$ - commerce business model.

(3) Study the M-commerce model.

\section{RESEARCH METHODOLOGY}

Questionnaire and their analysis using as research methodology.

\section{HYPOTHESIS}

(1) M-commerce transaction can be performed through broadcasting agent and their receivers.

(2) Broadcasting agents and its receiving agent based M-commerce transaction can be performed automatically and semi automatically.

(3) M-commerce's broadcasting and It's receiving agent based model functioning in the market.

\section{BROADCASTING AND IT'S RECEIVING AGENT BASED M-COMMERCE BUSINESS MODEL}

The work refers the "broadcasting and It's receiving agent based m-commerce business model". ${ }^{[3]}$ There is an architecture which has depicted the whole concept of the broadcasting and It's receiving agent based $\mathrm{m}$-commerce business model. There are broadcasting agent like Radio Broadcasting, Telephone Broadcasting, Satellite Broadcasting, Telephone Broadcasting, Cable Radio Broadcasting, Web Casting. Almost all the broadcasting agents broadcast the business contain or goods. There are broadcast receiving agent like Radio Broadcasting Receiver, Telephone Broadcasting Receiver, Television Broadcasting Receiver, Cable Radio Broadcasting Receiver, Web casting Receiver. The broadcasting based network or 3G network observed between broadcasting agents and broadcast receiving agents. Business Transaction occurred between broadcast receiving agent and customer, user, Audience and Spectators. As indicated in the architecture there is a phone, 3G technology based phone or order sending agent or some mobile or NFC Agent or providing sensor information in the form of digital or analog or Image for order sending. There is NFC network, Sensor Network or WSN between Embedded System included order receiving agent, data authentication, credit conformation and business firm.

The order receiving agent compare mobile sensor node or NFC receiving Agent or digital data sensor or analog data sensor. The business firm provides goods automatically what is sending info by sensor from firm. Thus the firm send automatic way of sending goods for broadcasting agents. These whole transaction considered as a automatic transaction. So as semi automatic transaction have established by the customer, user, audience or spectators. Customer, User, Audience or Spectators using mobile for establishing business order. Order sending agent for semi automatic transaction included by mobile call, by mobile message, by e-mail through mob by ecom, m-com sites. There is broadcasting based network or $3 \mathrm{G}$ network. Data authentication occurred after that process. Then after order receiving agent like 3G mobile, Computer with internet, $3 \mathrm{G}$ Television, Data receiver. At last in the semi automatic transaction there is business firm. The business firm send data, send advertise, send services as goods as broadcasting, send goods directly or make communication. Semi automatic transaction 
sends goods or business contain to the broadcasting agent for broadcasting. Some time semi automatic transaction send goods directly or make communication, obtained the goods by the customer, user spectator, audience directly. Some time communication established once again through the user, customer, spectators, audience with the mobile or $3 \mathrm{G}$ mobile and would place order for business.

\section{- Architecture of the Model}

The research work depicted an architecture as per below. ${ }^{[3]}$

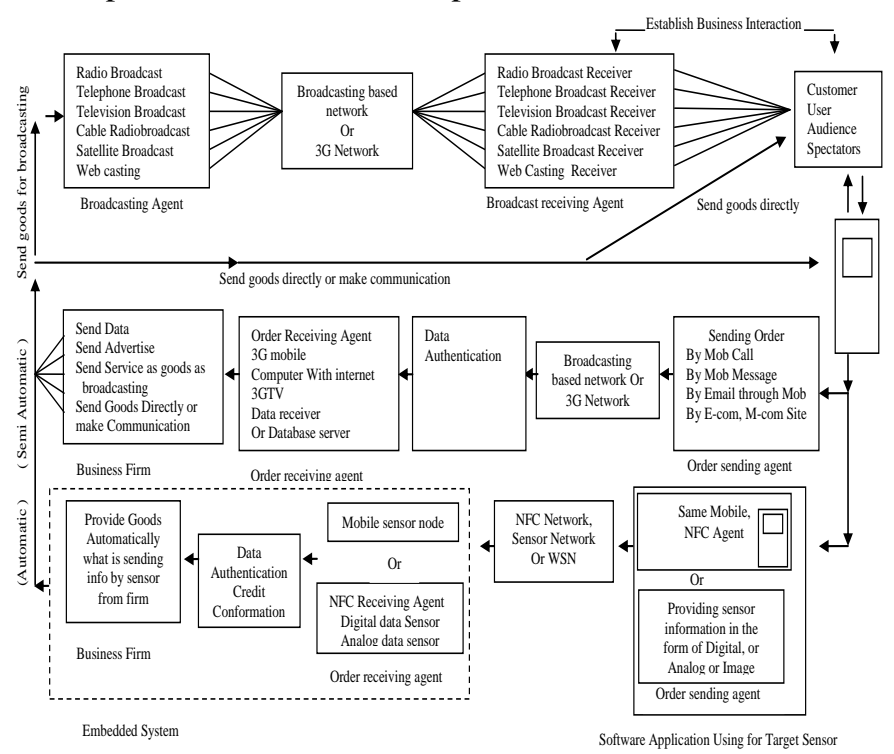

Figure 1: Architecture of the broadcasting and its receiving agent based M-Commerce model.

\section{-Driving Factors}

Driving Factors depicted as per below. ${ }^{[2],[4]}$

1. Existing Driving Factors: The business model has depicted driving factors as per below mention. ${ }^{[2]}$

(i) The modernization of technology

(ii) A consideration of new value chain and demand for customer.

\section{Advance driving factors:}

(1) Rapid Growth Of Customer Use and Adoption of The Broadcasting Agents and Receivers. ${ }^{[4]}$

\section{- Transaction of the Model}

Transaction through agent of the model mention as per below. ${ }^{[3]}$

Agent 1 : Radio broadcast receiving agent based transaction.

Example 1 :

Purchase a tooth paste by listening radio broadcast receiving agent as advertise and contact to the company by mobile call or email or by message instructed in the advertise. ${ }^{[3]}$

Example 2 :

Goods or service obtains as radio broadcasting. RA 123 private business radio fee per $2 * 12.5 \mathrm{khz}$.

Channel is based upon whether the channel used nationally or regionally and the frequency band used. ${ }^{[3]}$

Private mobile radio (standard).

$$
\begin{aligned}
& 140 \text { for up to } 10 \text { mobile stations. } \\
& 250 \text { for } 11-15 \text { mobile stations } \\
& 500 \text { for } 26-60 \text { mobile stations } \\
& 1000 \text { for } 61-100 \text { mobile stations } \\
& 1750 \text { for } 101-200 \text { mobile stations } \\
& 3500 \text { for } 201-500 \text { mobile stations } \\
& 7000 \text { for } 501-1000 \text { mobile stations }
\end{aligned}
$$

For more than 1000 mobile stations 7000 for first thousand plus.

Agent 2: Telephone broadcasting receiving agent

Example 1 : M-commerce transaction based on Telephone broadcasting agent.

The model instructs that there are recorded telephone call for customer for a products like a books and CD or DVD for spoken English. A customer or listener can listen and may contact to the business firms for goods or they are listing CD or DVD for learning English.

Example 2 : Goods or service as telephone broadcasting. 
Pay for ring tones, songs, cricket commentary services by telephone service provider like Airtel,Voda phone ,Reliance telecom.

Agent 3 : Television broadcasting receiving agent

Example 1 : Naptol, Sales India, Asian sky shop are the payable business provider in India. The person using its phone number, contact for establishing business.

Example 2: Content on YouTube -pay news network channel. for establishing business.

Agent 4 : Cable radio broadcasting receiving agent

Example 1: United States and Canadian people using cable radio for delivering emergency information or providing business information.

Agent 5 : Satellite broadcasting receiving agent

Example 1 : (D2H) Direct to Home service in India payable receiver based program. Satellite played key role for establishing business transaction.

Agent 6 : Web casting Receiving Agent

Example 1: Website based business and $\mathrm{E}^{*}$ Trade provide live and on demand streaming services through internet.

\section{ADVANCE EQUETION AND M_COMMERCE MODEL}

\section{Equation For Deciding MDF (M-Commerce Driving Factor) :}

For constructing M-commerce model the driving factor is important. The equation and its related case studies and parameters proves the M-commerce driving factor depend on $\mathrm{m}$-commerce transaction variables. ${ }^{[4]}$

$$
\sum_{i=1}^{n} \operatorname{Tr} . \mathrm{V}_{(\mathrm{i})} \rightarrow \mathrm{MDF}
$$

The business transaction variable is important for recognizing or deciding of the M-Commerce driving factor. Broadcasting and its receiving agent constructing transaction, which shows the dependency with MDF (M-commerce driving factors). At the end rapid growth of customer use and adoption of the broadcasting agent and receiver proved as driving factor. ${ }^{[4]}$

\section{Equation for deciding MM (M-commerce Model)}

MM (M-commerce Model) has dependency with MDF. The M-commerce driving factor is the aspect which construct MM (M-commerce Model). The equation and its related case studies and parameters proves the M-commerce Model. ${ }^{[5]}$

$$
\sum_{i=1}^{n} \operatorname{Tr} . \mathrm{V}_{(\mathrm{i})} \rightarrow \mathrm{MDF} \rightarrow \mathrm{MM}
$$

Using the above mention equation, Broadcasting agent and its receive agent based $\mathrm{MM}(\mathrm{m}$-commerce model) shows the dependency with Broadcasting agent and its receive agent based MDF. Broadcasting agent and its receive agent based MDF shows the dependency with Broadcasting agent and its receive agent based transaction. ${ }^{[5]}$

\section{Equation For MM(M-commerce Model) has dependency with (MDF) M-commerce driving factor}

$$
\mathrm{MDF} \rightarrow \mathrm{MM}
$$

Broadcasting and its receiving agent based MM M-commerce model shows the dependency with Broadcasting and its receiving agent based (MDF) M-commerce driving factors. ${ }^{[5]}$

The equation and its related case studies and parameters proves the M-commerce Model. ${ }^{[5]}$

\section{Equation for deciding MM is showing dependencies with transaction variables.}




$$
\sum_{i=1}^{n} \operatorname{Tr} . \mathrm{V}_{(\mathrm{i})} \rightarrow \mathrm{MM}
$$

Broadcasting and its receiving agent based MM (M-commerce Model) directly shows the dependences with broadcasting and its receiving agent based transaction variables. ${ }^{[5]}$ The equation and its related case studies and parameters proves the M-commerce Model. ${ }^{[5]}$

\section{OBSERVATION OF TRANSACTIONS AND DATA COLLECTION}

The study indicates the explanations of transaction based on broadcasting and its receiving agent based M-commerce model.

Ninety (90) questionnaire contains Nineteen (19) questions at first section and Eleven (11) questions at second section have filled by the technocrats of the area. North Gujarat, a state of India chosen as an aria for the filling of the questionnaire. Technocrats of the area have performed the transaction. The work observed the transaction of the M-commerce's broadcasting receiving agent based model.

Questionnaire based observation 1: Radio broadcasting

and its receiving agents based transaction done by the technocrats of the North Gujarat, India.

Q 1 What have you purchased after listening radio broadcasting advertisement and placed order using mobile phone?

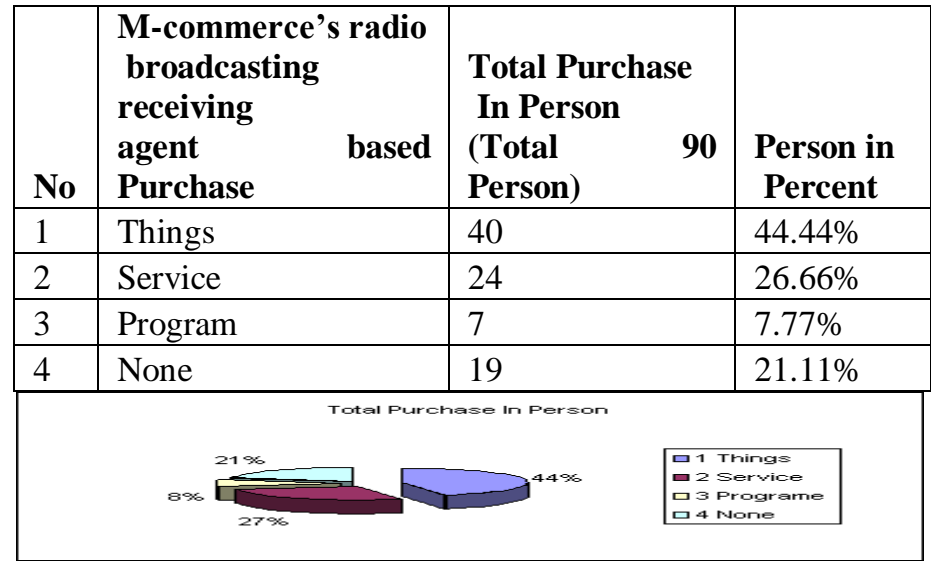

Questionnaire based observation 2: Television broadcasting and It's receiving agents based transaction done by the technocrats of the North Gujarat, India. Q 2 What have you purchased after watching Television based advertisement and placed order using mobile phone?

\begin{tabular}{|c|c|c|c|}
\hline No & $\begin{array}{l}\text { M-commerce's Television } \\
\text { broadcasting receiving } \\
\text { agent based Purchase }\end{array}$ & $\begin{array}{l}\text { Total Purchase } \\
\text { In Person }\end{array}$ & Percentage \\
\hline 1 & Things & 24 & $26.66 \%$ \\
\hline 2 & Service & 18 & $20.00 \%$ \\
\hline 3 & Program & 37 & $41.11 \%$ \\
\hline 4 & None & 11 & $12.22 \%$ \\
\hline \multicolumn{4}{|c|}{ Total Purchase in Person } \\
\hline \multicolumn{3}{|c|}{$E^{12 \infty}$} & 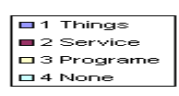 \\
\hline
\end{tabular}

Questionnaire based observation 3: Web casting and

It's receiving agent based transaction done by the technocrats of the North Gujarat, India.

Q 3 What have you purchased after watching Web site based advertisement and placed order using mobile phone? 


\begin{tabular}{|c|c|c|c|}
\hline No & Item & Total Purchase In Person & Percent \\
\hline 1 & Things & 19 & $21.11 \%$ \\
\hline 2 & Service & 32 & $35.55 \%$ \\
\hline 3 & Program & 29 & $22.22 \%$ \\
\hline 4 & None & 10 & $11.11 \%$ \\
\hline & $32 \%$ & Total Purchase in Person & 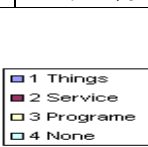 \\
\hline
\end{tabular}

Q 4 What have you purchase after watching advertisement from network administrator on computer (IP based) and placed order using mobile phone?

\begin{tabular}{|l|l|l|l|}
\hline No & Item & Total Purchase In Person & Per. \\
\hline 1 & Things & 19 & $21.11 \%$ \\
\hline 2 & Service & 24 & $26.66 \%$ \\
\hline 3 & Program & 24 & $26.66 \%$ \\
\hline 4 & None & 23 & $25.55 \%$ \\
\hline \multicolumn{2}{|c|}{} \\
\hline
\end{tabular}

Questionnaire based observation 4: Satellite broadcasting and its receiving agent based transaction done by the technocrats of the North Gujarat, India.

Q 5 What have you purchased using D2H ("Direct To Home" A satellite based TV Service ) based advertisement, and placed order using mobile phone?

\begin{tabular}{|c|c|c|c|}
\hline No & Item & Total Purchase In Person & Percent \\
\hline 1 & Things & 16 & $17.77 \%$ \\
\hline 2 & Service & 35 & $37.77 \%$ \\
\hline 3 & Program & 18 & $20.00 \%$ \\
\hline 4 & None & 22 & $24.44 \%$ \\
\hline \multicolumn{3}{|c|}{ 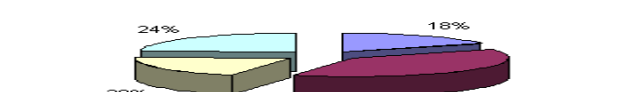 } & 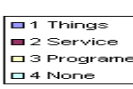 \\
\hline
\end{tabular}

Questionnaire based observation 5: Telephone Broadcasting and It's Receiving Agent based transaction done by the technocrats of the North Gujarat, India.

Q 7 What have you purchased after listening mobile phone based advertisement, and placed order using mobile phone?

\begin{tabular}{|c|c|c|c|}
\hline No & Item & Total Purchase In Person & Percent \\
\hline 1 & Things & 16 & $17.77 \%$ \\
\hline 2 & Service & 43 & $47.77 \%$ \\
\hline 3 & Program & 29 & $22.22 \%$ \\
\hline 4 & None & 2 & $2.22 \%$ \\
\hline & & $\begin{array}{l}\text { Total Purchase in Person } \\
2 \% \quad 18 \%\end{array}$ & 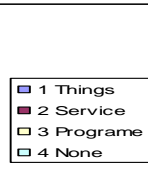 \\
\hline
\end{tabular}

Questionnaire based observation 6: Automatic transaction and 
Broadcasting and It's Receiving Agent Based M-commerce Business Model Functioning In The

obtains goods as broadcasting contains(Program). Broadcasting agent sends it to broadcasting receiving agent.

Q 8 What recharge or payments have done by using Internet using mobile phone?

\begin{tabular}{|c|c|c|c|}
\hline No & Item & Total Purchase In Person & Pre. \\
\hline 1 & Telephone Bill & 39 & $43.33 \%$ \\
\hline 2 & Television Program & 15 & $16.66 \%$ \\
\hline 3 & Other Things & 22 & $24.44 \%$ \\
\hline 4 & None & 14 & $15.55 \%$ \\
\hline
\end{tabular}

Questionnaire based observation 7: Broadcasting Receiving agents have used by the technocrats of the North Gujarat, India, and placing order on mobile phone.

Q 13 Which receiver used for business transaction and placing order by phone?

\begin{tabular}{|c|c|c|c|c|}
\hline No & Broadcasting Receiver & $\begin{array}{l}\text { Total Us } \\
\text { of receiv } \\
(90+90=\end{array}$ & $\begin{array}{l}\text { ser } \\
\text { ver In Person } \\
\text { =180) }\end{array}$ & Per. \\
\hline 1 & Radio Receiver & 7 & & 4 \\
\hline 2 & Television (As receiver) & 31 & & 17 \\
\hline 3 & Satellite based receiver & 37 & & 21 \\
\hline 4 & None & 23 & & 13 \\
\hline 5 & Telephone as receiver & 35 & & 19 \\
\hline 6 & Web casting based receiver & 36 & & 20 \\
\hline 7 & Cable radio based receiver & 11 & & 6 \\
\hline \multicolumn{5}{|c|}{ 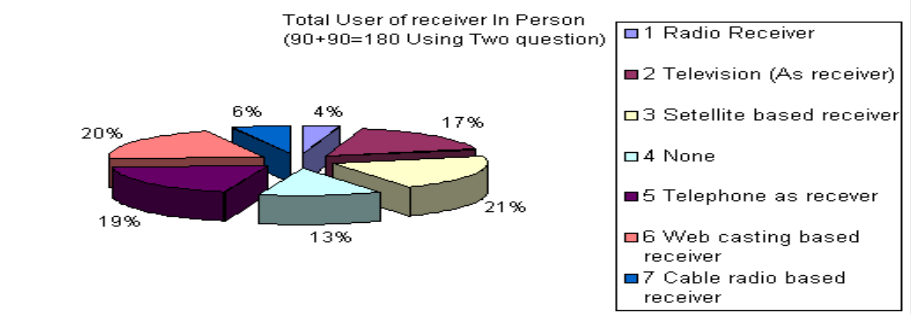 } \\
\hline
\end{tabular}

Q 14 Which another receiver used for business transaction and placing order by phone?

\begin{tabular}{|l|l|l|}
\hline $\begin{array}{l}\text { Item to be selected on the basis of frequent advertisement on the broadcasting receiving agent and all } \\
\text { the remaining Items put in other things header }\end{array}$ \\
\hline & $\begin{array}{l}\text { Item to be purchased by using radio broadcasting receiver and } \\
\text { placed order on mobile phone }\end{array}$ & $\begin{array}{l}\text { Quantities in person } \\
\text { (Total 90) }\end{array}$ \\
\hline 1 & Tooth Paste & 22 \\
\hline 2 & Talcum Powder & 5 \\
\hline 3 & Milk Vitamin Powder & 12 \\
\hline 4 & Lic Policy & 29 \\
\hline 5 & Other things & 18 \\
\hline 6 & Not selected Item & 4 \\
\hline
\end{tabular}




\begin{tabular}{|c|c|c|}
\hline No & $\begin{array}{l}\text { Item to be purchased by using Television broadcasting receiver } \\
\text { and placed order on mobile phone }\end{array}$ & $\begin{array}{l}\text { Quantities in person (Total } \\
\text { 90) }\end{array}$ \\
\hline 1 & Shampoo for hair & 21 \\
\hline 2 & Viks Veporub & 11 \\
\hline 3 & Ice-cream & 14 \\
\hline 4 & Cloths & 17 \\
\hline 5 & Other things & 22 \\
\hline 6 & Not selected Item & 5 \\
\hline No & $\begin{array}{l}\text { Item to be purchased by using Satellite based broadcasting } \\
\text { receiver and placed order on mobile phone }\end{array}$ & $\begin{array}{l}\text { Quantities in person (Total } \\
\text { 90) }\end{array}$ \\
\hline 1 & A Special Program & 28 \\
\hline 2 & Dish TV Recharge & 25 \\
\hline 3 & A Medicine & 15 \\
\hline 4 & Washing Powder & 8 \\
\hline 5 & Other things & 10 \\
\hline 6 & Not selected Item & 4 \\
\hline
\end{tabular}

\begin{tabular}{|l|l|l|}
\hline No & $\begin{array}{l}\text { Item to be purchased by using Web casting based } \\
\text { broadcasting receiver and placed order on mobile phone }\end{array}$ & $\begin{array}{l}\text { Quantities } \\
\text { person } \\
\text { Total 90 }\end{array}$ \\
\hline & $\begin{array}{l}\text { Past purchase Antivirus software and placing order as old } \\
\text { customer from anti virus company (Order is placing on selected IP } \\
\text { Internet Address From Customer side to company side) }\end{array}$ & 35 \\
\hline & $\begin{array}{l}\text { Past purchase software (Except Antivirus ) and placing order as } \\
\text { old customer from company (Placing Order on selected IP } \\
\text { Internet Address From customer side to company side ) }\end{array}$ & 35 \\
\hline & $\begin{array}{l}\text { Past Purchase Other Things viewed on Website and placing } \\
\text { order(Order is placing on selected IP Internet Address From } \\
\text { customer side to company side) }\end{array}$ & 20 \\
\hline 4 & Not selected Item & 5 \\
\hline & $\begin{array}{l}\text { Name the purchase thing from Shopping Mall and have used } \\
\text { swipe machine and credit or debit card for payment and } \\
\text { placed order from company using mobile. }\end{array}$ & $\begin{array}{l}\text { Quantities } \\
\text { in } \\
\text { (Total 90) }\end{array}$ \\
\hline 1 & Grocery Item from company & 12 \\
\hline 2 & Cloths from company & 19 \\
\hline 3 & Toys & 11 \\
\hline 4 & Electronics Item & 25 \\
\hline 5 & Other things & 20 \\
\hline 6 & Not selected Item & 3 \\
\hline
\end{tabular}

Secondary Data for Cable Radio Broadcasting: United States and Canadian people using cable radio for delivering emergency information or providing business information. There was a CABL-FM 108 working as commercial purpose. ${ }^{[6]}$

\section{DATA ANALYSIS}

- Broadcasting and Its receiving agent based M-commerce Transaction performed as per below mention.

1. Observation 1: Radio Broadcasting Receiving Agent

2. Observation 2: Television Broadcasting Receiving Agent

3. Observation 3: Web casting Broadcasting Receiving Agent 
4. Observation 4: Satellite Broadcasting Receiving Agent

5. Observation 5: Telephone Broadcasting Receiving Agent

6. Observation 6: Automatic Transaction

- Data to be obtained using questionnaire:

(1) Radio broadcasting receiver based purchase: 71 Person has performed business transaction for different type of Items (Things, Service, Program, None)out of 90 Person.

(2) Television broadcasting receiver based purchase: 79 Person has performed business transaction for different type of Items (Things, Service ,Program, None)out of 90 Person.

(3) Web casting broadcasting receiver based purchase: 80 Person has performed business transaction for different type of Items (Things, Service,Program, None)out of 90 Person.

(4) Satellite broadcasting receiver based purchase: 68 Person has performed business transaction for different type of Items (Things, Service ,Program, None)out of 90 Person.

(5) Telephone broadcasting receiver based purchase: 88 Person has performed business transaction for different type of Items (Things, Service ,Program, None)out of 90 Person.

Analysis from secondary data: Broadcasting and its receiving agent based M-commerce transaction performing on a cable radio broadcasting agent at U S A an have used the broadcasting receiver for delivering emergency information or providing business information.

\section{RESULT AND CONCLUSSION}

As per the hypothesis, objective, observation and data analysis the work has obtained the result.

(1) M-commerce transaction can be performed through (6) six broadcasting agents and their six receivers. Two Questions of 90

\begin{tabular}{|l|l|l|l|}
\hline No & Broadcasting Agent & Broadcasting Receiving Agent & $\begin{array}{l}\text { Transaction } \\
\text { Observed }\end{array}$ \\
\hline 1 & Radio Broadcasting & Radio Receiver & 7 out of 180 \\
\hline 2 & Television Broadcasting & Television as Receiver & 31 Out of 180 \\
\hline 3 & Web casting & -Computer System -Mobile with internet & 36 Out of 180 \\
\hline 4 & Satellite Broadcasting & Satellite Broadcasting Waves Receiver & 37 Out of 180 \\
\hline 5 & Telephone Broadcasting & Mobile Phone as Receiver & 35 Out of 180 \\
\hline 6 & Cable Radio Broadcasting & Cable Radio As Receiver & 6 Out of 180 \\
\hline
\end{tabular}

(2) Broadcasting agent and its receiving agents based M- Commerce transaction can be performed automatically and semi automatically. As per the observation of the study denoted automatic and semi automatic transaction. From observation 6.

\begin{tabular}{|l|l|l|l|}
\hline 2 & Television Program & 15 & $16.66 \%$ \\
\hline
\end{tabular}

(3) All the transaction, equation, and data prove Broadcasting agent and its receiving agent based Mcommerce model functioning in the market.

\section{REFERENCES}

[1] Jason J Zhang, Yufei Yuan,Norman Archar, Driving Force for M-commerce success. Indicates Driving Factors.

[2] Norman Sadeh, M-commerce Technologies, Services and Business Models.

[3] Trivedi Jaydipkumar, Dr J.G Pandya, Dr Ashish N Jani, Trivedi Prakashkumar Hitendrabhai Broadcasting and It's Receiving Agent Based M-commerce Business Model. Presented as Poster Presentation in Cross Disciplinary International Seminar at H N G U, Patan. India on 15 June 2011, It is subjected to publish in the university Journal.

[4] Trivedi Jaydipkumar Hitendrabhai, Dr J G Pandya, Trivedi Prakash H, Patel Jignasha B Rapid Growth Of Customer Use and Adoption of The Broadcasting Agent and Receiver: A Driving M-commerce Factor.IOSRJEN Vol 1-Issue 12011

[5] Trivedi Jaydipkumar Hitendrabhai, Dr J G Pandya, Patel Jagdish M, Mithapare Anita K, M-commerce Driving Factors and Transaction Variables: Aspect That Construct The $\mathrm{M}=$ commerce model. International Organization of Scientific Research, Vol 1-Issue 22011

[6] http://en.wikipedia.org/wiki/cable-radio, 23 August 2012 